\title{
The impact of organic manure and nano- inorganic fertilizers on the growth, yield and oil content of sunflowers under well-watered conditions
}

\section{Mohsen Janmohammadi*,}

Akbar Seifi,

Mokhtar Pasandi,

\author{
Naser Sabaghnia \\ Department of Agronomy \\ and Plant Breeding, \\ Faculty of Agriculture, \\ University of Maragheh, \\ P.O. Box 55181-83111, \\ Maragheh, Iran
}

The sunflower is the third most important source of edible oil and accounts for about $14 \%$ of world production of seed oils. Although the sunflower is well adapted to semi-arid regions, low soil fertility and nutrients deficiencies are important yield-limiting factors for sunflower production. The current experiment was carried out to study the effects of farmyard manure (zero $\left(M_{1}\right)$, $\left.20\left(\mathrm{M}_{2}\right) \mathrm{tha}^{-1}\right)$ and nanostructured fertilizers $(\mathrm{Mn}, \mathrm{Fe}, \mathrm{Zn})$ on the agronomical traits, yield and yield components of the common sunflower (Helianthus annuus L.). The experiment was conducted during 2015-2016 growing seasons at a research field in Maragheh in the north-western part of Iran. Application of farmyard manure significantly improved such agronomic traits as plant height, leaf area, the number of leaves, the internode length, the stem diameter, the diameter of the branch head, the number of branches, the length of branches, achene length and achene width, the main capitulum diameter, 100-achene weight, oil content in an achene compared with non-manure condition. Results revealed that plants grown under $\mathrm{M}_{2}$ showed earlier flowering and possessed a higher chlorophyll concentration in leaves. Moreover, application of nano-chelated $\mathrm{Zn}$ and Fe considerably decreased the proportion of empty achenes and increased oil concentration, the achene yield and the harvest index. However, the best performance was obtained by combined application of nano-chelated $\mathrm{Zn}$ under manure conditions. The findings pointed to the importance of micronutrient deficiencies and balanced nutrition in this area. The overall results show that the integrated application of organic manure and nano-chelated micronutrients are more effective in improving the yield of sunflowers in semiarid production systems.

Keywords: achene yield, agronomic traits, farmyard manure, nanosized micronutrients, zinc oxide

\footnotetext{
*Corresponding author. E-mail: jmohamad@alumni.ut.ac.ir
} 


\section{INTRODUCTION}

The common sunflower (Helianthus annuus L.) is an annual erect broadleaf oilseed crop with a strong tap root system. Most of the area of sunflower cultivation lies in arid and semiarid regions due to its wide adaptability, suitability to mechanization, low labour needs, and high protein and oil contents (Canavar et al., 2010). Although sunflowers perform well across vast climatic and soil conditions (Nasim et al., 2016), they are quite responsive to agronomic practices, soil moisture, planting time and efficient nutrition management in accordance with local climatic and soil factors. However, in the Mediterranean semi-arid region the sunflower is still facing low production and productivity challenges which may partly be attributed to poor soil fertility, inappropriate nutritional management, and poor agronomic practices (Ryan, 2008; Ryan et al., 2012).

It has been estimated that world production of sunflower seeds exceeded 44.7 million tonnes from 25.5 million hectares of land (FAOSTAT. 2013). The annual production of sunflower seeds in Iran is close to 90,000 tonnes from 70,000 hectares (FAOSTAT. 2013). However, the average yield of this crop in the semi-arid region is relatively low. The potential of high-yield modern variety can only be fully exploited by careful application of inputs at proper growth stages.

Although the conditions of soil and water are vastly different from place to place, all plants need permeable soils with high organic matter and sufficient concentrations of essential elements for acceptable growth. Therefore a balanced fertilization strategy with macro and micronutrients in plant nutrition is highly imperative for crop production in these areas.

Among agronomical practices, the advantages of the utilization of plant residues or farmyard manure for improving the physicochemical properties of soil have been partially recognized (Rudrappa et al., 2006). The soil of semi-arid regions of Iran is intensively tilled; it is low in organic matter content and, consequently, has weak structural stabilities (Shirani et al., 2002). In literatures several researchers showed the importance of farmyard manure on increasing crop yield. Farmyard manure is rich in nutrients and can supply all major macronutrients $(\mathrm{N}, \mathrm{P}, \mathrm{K}, \mathrm{Ca}, \mathrm{Mg}, \mathrm{S})$ essential for plant development, as well as micronutrients. A small portion of its nitrogen is readily available for plant uptake and a large portion is released during and after decomposition (Mwahija, 2015). Application of farmyard manure significantly increases the organic matter content in soil. The organic matter serves as a reservoir of nutrients and water in the soil, helps to reduce compaction and surface crusting, and increases water infiltration into the soil (Schmidt et al., 2011). Furthermore, it can increase the availability of nutrients for plant uptake; it improves soil physical properties such as structure and water holding capacity, and creates suitable environment for the activity of soil microorganisms (Mwahija, 2015).

Micronutrients are nutrients required by plants in small quantities throughout their life to organize a range of physiological functions (Marschner, 2012). Although these elements are used in very small amounts, they are just as important to plant development and profitable crop production as the macronutrients. Among the micronutrients, manganese, iron and zinc are essential for crop growth and food production. Manganese $(\mathrm{Mn})$ is an important plant mineral nutrient that plays a key role in several physiological processes, particularly photosynthesis, lignin synthesis, and stress tolerance (Alloway, 2008). It also has a key role in the activation of enzymes involved in nitrogen metabolism (glutamin synthetase, arginase), gibberellic acid biosynthesis, RNA polymerase activation, and fatty acid biosynthesis (Hänsch, Mendel, 2009). Iron $(\mathrm{Fe})$ is involved in the production of chlorophyll, in photosynthesis, mitochondrial respiration, hormone biosynthesis (ethylene, gibberellic acid, jasmonic acid), production and scavenging of reactive oxygen species, and osmoprotection (Marschner 2012). Besides, zinc is a necessary component of various enzyme systems for energy production, protein synthesis, and energy production; it maintains the structural integrity of biomembranes and growth regulation 
(Alloway, 2008; Hänsch, Mendel, 2009; Marschner, 2012). However, the soil of the Mediterranean semi-arid regions is characterized by poor structure, low organic carbon content, high $\mathrm{pH}$, low cation exchange capacity and salinity/alkalinity problems, and these conditions exacerbate micronutrient deficiencies.

It has often been argued that intensive application of chemical fertilizers began during the Green Revolution, in order to meet high nutrient requirements of high-yielding varieties (Evenson, Gollin, 2003). It seems that there exists some significant interaction between farmyard manure application and efficiency of micronutrient fertilizer (Gorttappeh et al., 2000; El-Ghamry et al., 2009). Also, it has been revealed that a sunflower hybrid gave a higher yield from a combination of organic manures with chemical fertilizers (Munir et al., 2007). Although conventional chemical fertilizers have some advantages, their performance needs standard basic chemical and physical condition soils. It means that chemical fertilization has met with success only in some situations, and negative effects of conventional fertilizers application such as a high probability of leaching, spray drift (wind), volatilization, high energy consumption for their production, the risk of toxic chemicals, stimulation of the vegetative growth and depletion of soil water storage on plant growth in semi-arid region have been reported (Rai et al., 2015).

Nanotechnology is one of the most powerful tools in modern agriculture, and it is estimated to become a driving economic force in the near future. It is predicted that nanotechnology can boost agricultural production through the nano-formulations of agrochemicals and production of nanofertilizers (Sekhon, 2014). Nanofertilizers deal with active nutritional ingredients at nanoscale $(1-100 \mathrm{~nm})$ dimensions. When reduced to the nanoscale, these materials display some characteristics which differ from what they exhibit on a bulk scale, facilitating unique applications. Nanoparticles have large surface area to the volume ratio, which provides a better opportunity for interaction (Naderi, Danesh-Shahraki, 2013). The tools and mech- anisms used in nanofertilizers enable them to partially synchronize the nutrient release with crop requirements. In a new type of nanofertilizers the nutrients can be released in response to environmental factors (DeRosa et al., 2010). The present study was planned because so far there have been only few studies on the interaction of nanofertilizers and farm-yard manure. Keeping these aspects in view, the efficiency of nanofertilizers under different organic manure levels should be acknowledged clearly and this will create the angle of vision for the application of nanofertilizers in the semi-arid region.

\section{MATERIALS AND METHODS}

A field experiment with the sunflower hybrid Iroflor was carried out during 2015-2016 growing season in Maragheh $\left(46^{\circ} 16^{\prime} \mathrm{E}\right.$ and $37^{\circ} 23^{\prime} \mathrm{N}$ with an altitude of $1485 \mathrm{~m}$ ) in the north-west of Iran. The experiment was established on a silty loam soil ( $25 \%$ clay, $51 \%$ silt and $24 \%$ sand) with $\mathrm{pH} 8.07$, organic matter content $0.92 \%$, total nitrogen $0.13 \%$, Caco3 $17 \%$, electrical conductivity (EC) $0.8 \mathrm{ds} \mathrm{m}^{-1}$, phosphorous $15.31 \mathrm{ppm}$ and potassium $820 \mathrm{ppm}$ (0 to $60 \mathrm{~cm}$ depth). The previous crop in the experimental field was safflower (Carthamus tinctorius L.). Maragheh is representative of the highland semi-arid zone and has a mean annual temperature of $11{ }^{\circ} \mathrm{C}$ and annual rainfall of $375 \mathrm{~mm}$. The total rainfall during the growing season was $137 \mathrm{~mm}$. In this region irrigation is necessary because the rains were low and poorly distributed throughout the season.

The trial was performed in a split-plot experiment according to randomized complete block design with three replications keeping farmyard manure (zero $\left(M_{1}\right), 20\left(M_{2}\right) t$ ha) in main plots and nano-chelated micronutrient $(\mathrm{Mn}, \mathrm{Fe}, \mathrm{Zn})$ in sub plots. Chemical properties of farmyard manure included $31.4 \%$ of organic matter, $1.65 \%$ of total N, 850 ppm of available $\mathrm{P}$ and $3096 \mathrm{ppm}$ of available $\mathrm{K}, \mathrm{pH} 8.23$, Ec $3.1 \mathrm{ds} \mathrm{m}^{-1}$. The experimental fields were ploughed two times in early autumn and two week before planting, subsequently soil harrowed twice to bring the soil to fine tilth. After the second primary tillage operations, well rotten 
farmyard manure was applied as per treatment and thoroughly mixed into the top soil. Each plot was $4 \mathrm{~m}$ long and $3 \mathrm{~m}$ wide. Row-to-row and plant-to-plant (in a row) distances were $60 \mathrm{~cm}$ and $20 \mathrm{~cm}$, respectively. Sunflowers were sown on 3 April and harvested on 21 August, which is equivalent to 141 days from planting to harvesting. Two or three seeds were dibbled in each hill to facilitate better emergence and to provide uniform stand of plants. Thinning was attended at 10 to 12 days after sowing to retain one healthy seedling per hill.

Nano-chelated fertilizers were obtained from the Sepeher Parmis Company, Iran. They contained zinc oxide, ferric oxide and manganese (II) oxide nanoparticles. Synthesized nanoparticles were characterized morphologically by transmission electron microscopy (Fig. 1). Nano-chelated fertilizers were applied at the rate of $1 \mathrm{~kg} \mathrm{ha}^{-1}$ through fertigation 30 and 60 days after the sowing date. Surface irrigation was applied nine times during the growth season.

Weeding was done three times during the growth season. Hand hoes were used to keep the plots free from weeds. The first weeding was done when the seedlings were $5 \mathrm{~cm}$ tall with 3-4 true leaves and during vegetative growth stage 6 when plants had 12 to 14 true leaves. The last weeding was done during flowering at reproductive stage II (R2). There was no incidence of pest or disease on the plants during the experiment.

Leaf area was estimated at the end of the flowering stage (R 5.8). Leaf relative water content was estimated at upper leaves during the initiation of the flowering stage (R4) when the inflorescence began to open. For this purpose, five fresh leaves of the same size and same age of five plants from each treatment were collected and weighed $(\mathrm{Fw})$. Leaf segments were kept immersed in distilled water for $24 \mathrm{~h}$ at room temperature in the dark. The turgid weight (Tw) of the leaves were measured and then oven-dried at $80{ }^{\circ} \mathrm{C}$ for $72 \mathrm{~h}$ until constant weight and reweighting (Dw). The relative water content was determined as RWC $(\%)=[(F w-D w) /($ Tw-Dw $)] \times 100$ (Hayatu et al., 2014). Phenology and plant development were evaluated according to Schneiter and Miller (1981). Leaf number was measured during the initiation of the reproductive stage when terminal bud forms a miniature floral head rather than a cluster of leaves (R1). The chlorophyll concentration was measured with a hand-held dual wavelength meter (SPAD 502, Chlorophyll meter, Japan) in fully expanded upper leaves at the flowering stage. Plant height was measured from the soil surface to the top of the uppermost plant organ. Stem diameter measurements were taken from the same (second) internode of the plants throughout the trial.

The yield and yield components were recorded on ten randomly selected plants. Plants were harvested at physiological maturity (R9), when the bracts became yellow and brown. At maturity, the capitula were further separated into vegetative components and achenes. Filled and unfilled achenes were separated by hand and the number of achenes for each group was determined. The harvested capitula were sun
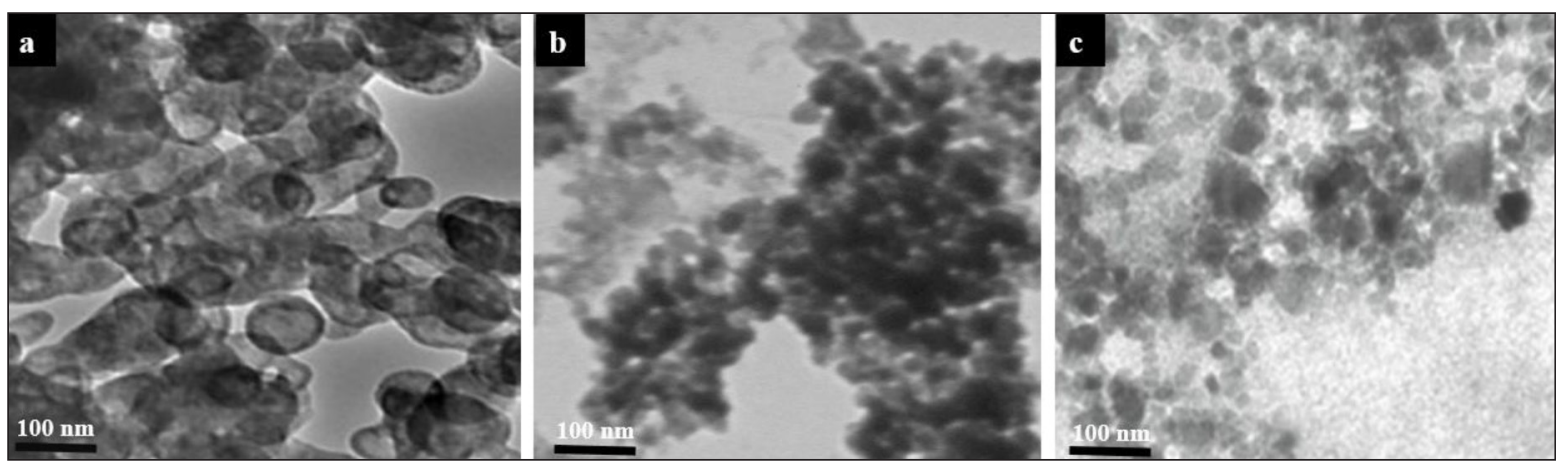

Fig. 1. Transmission electron microscopy (TEM) image of (a) synthesized nanoparticles of ferric oxide (b) manganese (II) oxide, and (c) zinc oxide utilized for nano-chelated fertilizers 
dried, and yield components such as the number of achenes per capitulum, empty achenes, 100-achene weight, achene length, achene width, and achene yield were recorded. Similarly, biological yield weight of harvested air dried plants (stalk + capitulum) was recorded on plot basis and then converted into $\mathrm{kg} \mathrm{ha}^{-1}$. The Harvest Index (HI) indicates the ratio of the achene yield to the biological yield. Oil concentration in mature achenes was measured using a Nearinfrared seed analyzer (Zeltex). Analysis of variances and mean comparison was performed using a SAS computer program and the least significant difference (LSD) test was utilized for the mean comparisons. Correlation analysis and principal component analysis (PCA), based on the rank correlation matrix and biplot analysis, were performed by SPSS v. 16, STATISTICA v. 8 and Minitab v.16.

\section{RESULTS}

Variance analysis for plant height revealed that this trait is significantly $(P<0.01)$ affected by farmyard manure and nanofertilizers (Table 1). Application of farmyard manure increased plant height up to $18 \%$ over control. On the other hand, evaluation of this trait between different levels of nanofertilizers showed that the tallest plants were obtained by the utilization of nano-chelated Fe and Zn. Likewise, leaf area noticeably responded $(P<0.01)$ to both types of fertilizers and the trend was largely similar to plant height (Table 1). Evaluation of the leaf number per plant also reflects this trend. It means that the application of farmyard manure and nano-chelated $\mathrm{Zn}$ increased the leaf number up to $44 \%$ and $13 \%$ over control.

Plants grown under manure conditions had significantly thicker stems compared to those grown under non-manure conditions. Also, the effect of nanofertilizers on the stem diameter was significant at the $5 \%$ level and the tickets stems was recorded for plants grown by nanochelated $\mathrm{Zn}$. Application of farmyard manure increased the internode length up to $33 \%$ over control. Furthermore, plant grown by nano-chelated $\mathrm{Zn}$ and $\mathrm{Fe}$ showed the longest internode. This trend was also observed for RWC (Table 1). Interaction effect of farmyard manure $\times$ nanofertilizers was significant for RWC, which means that the highest RWC was recorded for plants grown under concomitant application of farmyard manure and nano-chelated Zn or Fe (Fig. 1).

Table 1. The effect of farmyard manure and nano-chelated micro-nutrients on some morphological traits of the sunflower (Helianthus annuus L.)

\begin{tabular}{|c|c|c|c|c|c|c|c|c|c|c|}
\hline $\begin{array}{c}\text { Farm- } \\
\text { yard } \\
\text { manure }\end{array}$ & $\mathrm{PH}$ & LA & SD & IL & RWC & $\mathrm{CC}$ & DF & MCD & $\mathrm{DM}$ & $\mathrm{LN}$ \\
\hline & $* *$ & $* *$ & $* *$ & $* *$ & $* *$ & $* *$ & $* *$ & $* *$ & $* *$ & $* *$ \\
\hline non & $135.41^{\mathrm{a}}$ & $1951.25^{\mathrm{b}}$ & $17.76^{\mathrm{b}}$ & $4.99^{\mathrm{b}}$ & $54.56^{\mathrm{b}}$ & $43.33^{b}$ & $68.00^{\mathrm{a}}$ & $13.02^{\mathrm{b}}$ & $113.41^{\mathrm{b}}$ & $12.50^{\mathrm{b}}$ \\
\hline \multirow[t]{3}{*}{ with } & $159.50^{\mathrm{b}}$ & $2556.75^{\mathrm{a}}$ & $23.70^{\mathrm{a}}$ & $6.67^{a}$ & $66.60^{\mathrm{a}}$ & $55.10^{\mathrm{a}}$ & $60.33^{b}$ & $14.74^{\mathrm{a}}$ & $122.08^{\mathrm{a}}$ & $18.00^{\mathrm{a}}$ \\
\hline & \multicolumn{10}{|c|}{ Nano micro-nutrient } \\
\hline & $* *$ & $* *$ & * & * & $* *$ & * & * & * & $* *$ & $* *$ \\
\hline control & $132.83^{c}$ & $2178.75^{\mathrm{b}}$ & $18.55^{\mathrm{b}}$ & $5.75^{\mathrm{b}}$ & $58.96^{\mathrm{b}}$ & $44.62^{c}$ & $67.330^{\mathrm{a}}$ & $13.01^{\mathrm{c}}$ & $118.50^{\mathrm{b}}$ & $14.50^{\mathrm{b}}$ \\
\hline $\mathrm{Mn}$ & $141.83^{\mathrm{b}}$ & $2160.25^{\mathrm{b}}$ & $20.49^{\mathrm{b}}$ & $5.31^{\mathrm{b}}$ & $58.82^{\mathrm{b}}$ & $46.42^{\mathrm{bc}}$ & $68.00^{\mathrm{a}}$ & $13.72^{\mathrm{bc}}$ & $113.83^{c}$ & $15.33^{\mathrm{b}}$ \\
\hline $\mathrm{Fe}$ & $155.00^{\mathrm{a}}$ & $2314.50^{\mathrm{a}}$ & $20.67^{b}$ & $6.11^{\mathrm{a}}$ & $62.04^{\mathrm{a}}$ & $53.02^{\mathrm{a}}$ & $60.00^{\mathrm{b}}$ & $13.91^{\mathrm{b}}$ & $116.50^{\mathrm{bc}}$ & $15.50^{\mathrm{b}}$ \\
\hline $\mathrm{Zn}$ & $160.16^{\mathrm{a}}$ & $2362.25^{\mathrm{a}}$ & $23.21^{\mathrm{a}}$ & $6.16^{\mathrm{a}}$ & $62.50^{\mathrm{a}}$ & $51.79^{\mathrm{a}}$ & $61.00^{\mathrm{b}}$ & $14.87^{\mathrm{a}}$ & $122.16^{\mathrm{a}}$ & $16.33^{\mathrm{a}}$ \\
\hline $\mathrm{M} \times \mathrm{N}$ & NS & NS & NS & $*$ & $*$ & * & NS & NS & $* *$ & NS \\
\hline
\end{tabular}

$\mathrm{PH}=$ plant height at maturity, LA $=$ leaf area $\left(\mathrm{cm}^{2}\right), \mathrm{SD}=$ stem diameter $(\mathrm{mm}), \mathrm{IL}=$ internode length, RWC $=$ relative water content (\%), $\mathrm{CC}=$ chlorophyll concentration (SPAD unit), $\mathrm{DF}=$ days to $50 \%$ flowering, $\mathrm{MCD}=$ main capitulum diameter $(\mathrm{cm})$, $\mathrm{DM}=$ days to maturity, $\mathrm{LN}=$ leaf number. $\mathrm{M}=$ farmyard manure, $\mathrm{N}=$ micro-nutrient. $\mathrm{NS}=$ not significant, ${ }^{*}=$ significant at $5 \%$ level of probability, ${ }^{* *}=$ significant at $1 \%$ level of probability. Mean values of the same category followed by different letters are significant at $p \leq 0.05$ level. 
The chlorophyll concentration significantly responded to fertilizer treatments (Table 1). Mean comparison for the interaction effect of farmyard manure $\times$ nanofertilizers revealed that the highest chlorophyll concentration was obtained under manure condition with application of nano-chelated $\mathrm{Zn}$ and $\mathrm{Fe}$ and the lowest value was related to the plants grown under no-fertilizer condition (Fig. 2). Assessment of the main capitulum diameter showed that the application of farmyard manure improved this trait considerably. On the other hand, the plants grown with utilization of nanofertilizers had larger capitula compared to control, while the largest capitulum was obtained by the use of nano-chelated $\mathrm{Zn}$ (Table 1). The phenological development was significantly affected by fertilizer treatments. Although the application of farmyard manure and nanofertilizers accelerated the initiation of the flowering stage, their application led to the postponement of physiological maturity (Table 1). Application of nano-chelated Mn could not significantly affect the phenological development compared with control (no-fertilizer application). However, the plants grown under no-manure conditions showed early maturity. The highest number of days to maturity was recorded for the plants grown by application of farmyard manure along with nano-chelated $\mathrm{Zn}$. They were followed by the plants grown under manure conditions with non-application of nano- micronutrient fertilizers (Fig. 4).

The effect of farmyard manure and nano-chelated micronutrients on achene yield and yield components are shown in Table 2. The number of achene per capitulum is one of the most important yield components in the sunflower. Results revealed that the application of farmyard manure increased the number of achenes up to $17 \%$ over non-manure condition. Also, nanofertilizers could significantly improve this trait and

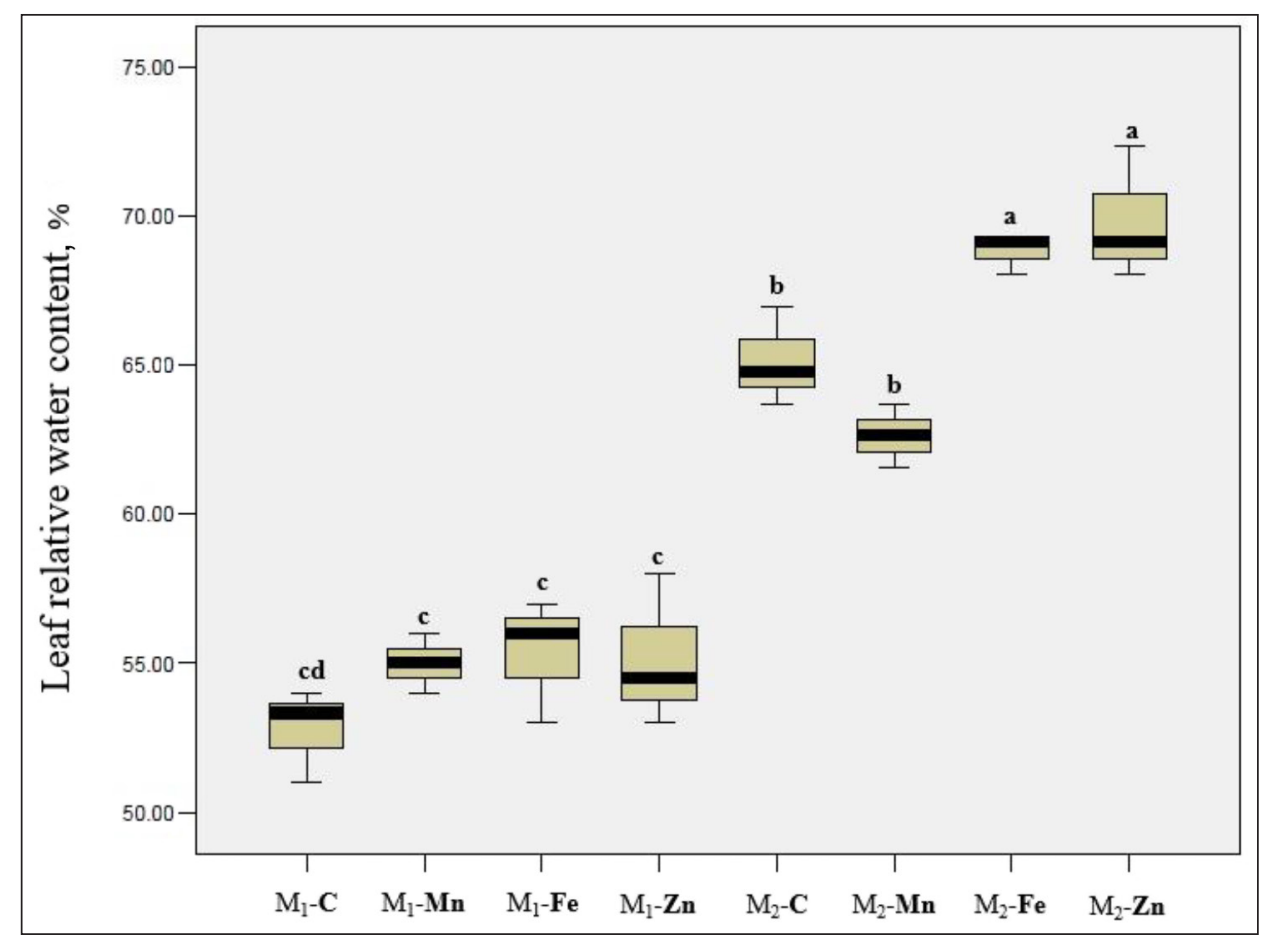

Fig. 2. The effect of farmyard manure and nano-chelated micronutrients on leaf relative water content of the sunflower. $M_{1}$ and $M_{2}$ : without and with $20 \mathrm{t} \mathrm{ha} \mathrm{a}^{-1}$ farmyard manure application, respectively. C: control (no-micronutrient application), Mn: nano-chelated manganese, Fe: nano-chelated iron, Zn: nano-chelated zinc. Values with the same letter were not significantly different 


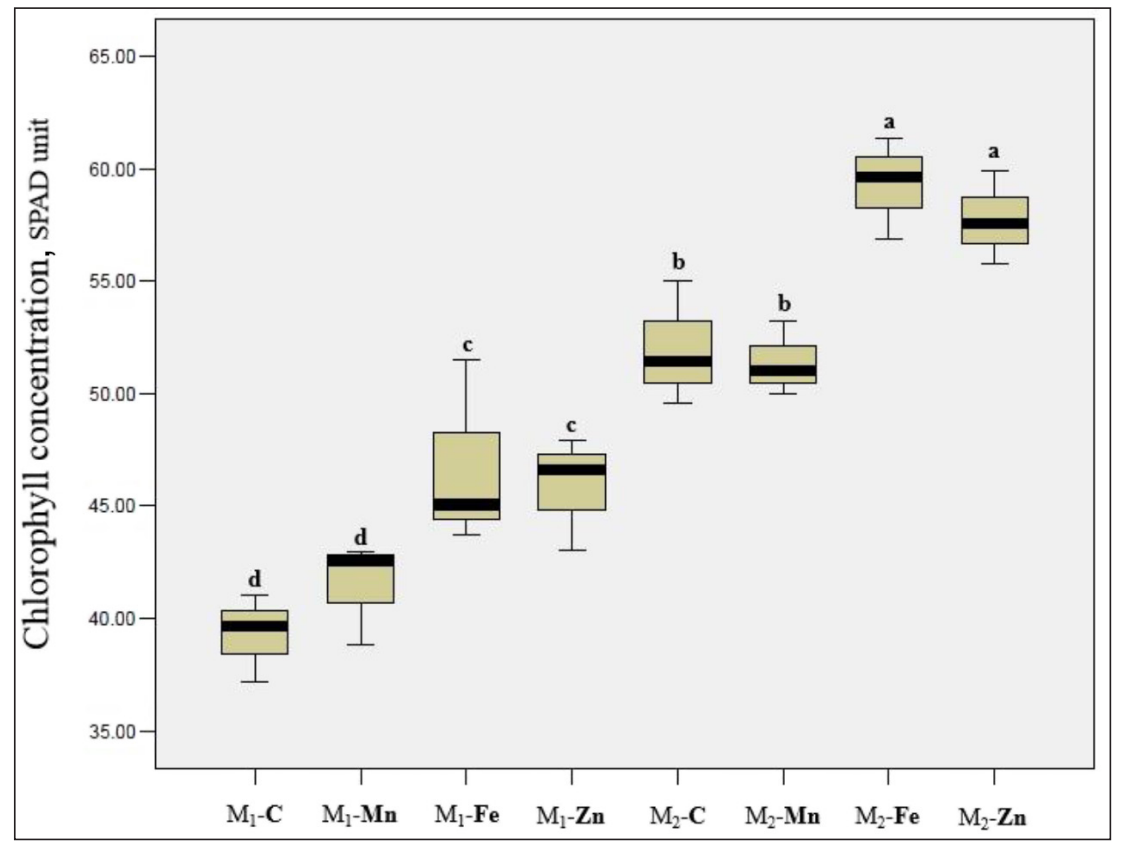

Fig. 3. Chlorophyll concentration of sunflower plants affected by farmyard manure and nano-chelated micronutrients in the semi-arid region of Marageh. $\mathrm{M}_{1}$ and $\mathrm{M}_{2}$ : without and with $20 \mathrm{t} \mathrm{ha}^{-1}$ farmyard manure application, respectively. C: control (no-micronutrient application), Mn: nano-chelated manganese, Fe: nano-chelated iron, $\mathrm{Zn}$ : nano-chelated zinc

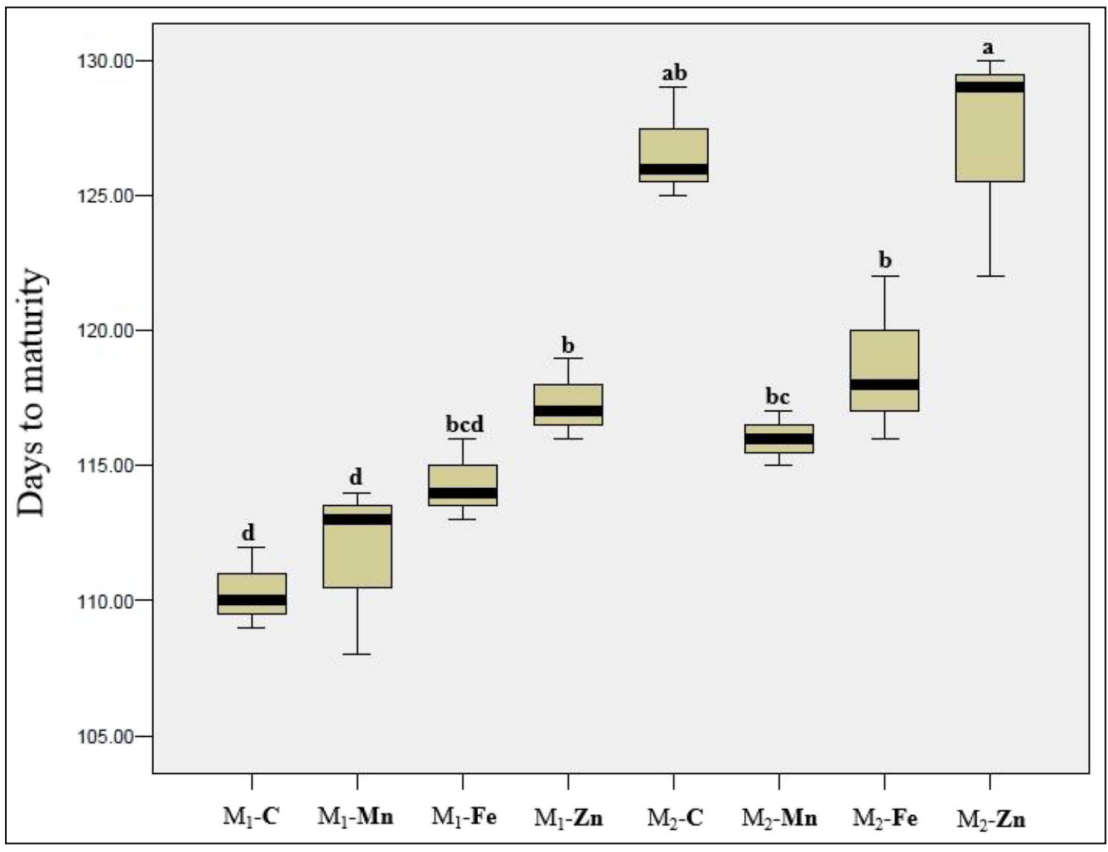

Fig. 4. The effect of farmyard manure and nano-chelated micronutrients on the number of days to maturity in sunflower plants in the semi-arid region of Marageh. $\mathrm{M}_{1}$ and $\mathrm{M}_{2}$ : without and with $20 \mathrm{t} \mathrm{ha}^{-1}$ farmyard manure application, respectively. C: control (no-micronutrient application) 
the highest achene number was recorded for the plants grown witch nano-chelated $\mathrm{Zn}$ and $\mathrm{Fe}$ under manure conditions (Fig. 5). A brief comparison of the influence of chemical nanofertilizers and farmyard manure on the number of achenes per capitulum indicated that the positive effect of manure was more prominent.

The percentage of empty achenes was also affected by the application of farmyard manure. Likewise, there was a significant interaction $(P<0.01)$ between farmyard manure and nanofertilizers. Mean comparison for the percentage of empty achenes showed that the lowest empty achenes were related to the plants grown with farmyard manure and nano-chelated $\mathrm{Zn}$. However, under non-manure conditions the lowest empty achenes was obtained by nanochelated Fe (Fig. 6). Evaluation of achene weight showed that the application of farmyard manure increased the 100 -achene weight up to $19 \%$ over non-manure conditions (Table 2). However, na- nofertilizers could not affect the achene weight. Assessment of the achene size revealed that both factors significantly affected the achene length, so that the application of farmyard manure increased this trait up to $13 \%$ over non-manure conditions. On the other hand, mean comparison between different levels of nanofertilizers showed that the longest achene was obtained by the application of nano-chelated Fe and $\mathrm{Zn}$. Achene width only responded to manure factor, so that the plants grown under manure conditions had wider achenes.

Under non-manure conditions, the application of the nanofertilizers could not affect the achene oil content, while the application of nano-chelated $\mathrm{Zn}$ and Fe under manure conditions significantly improved this trait (Fig. 7). Achene and biological yields significantly responded to both evaluated factors. Application of farmyard manure increased the achene yield up to $31 \%$ over the non-manure conditions.

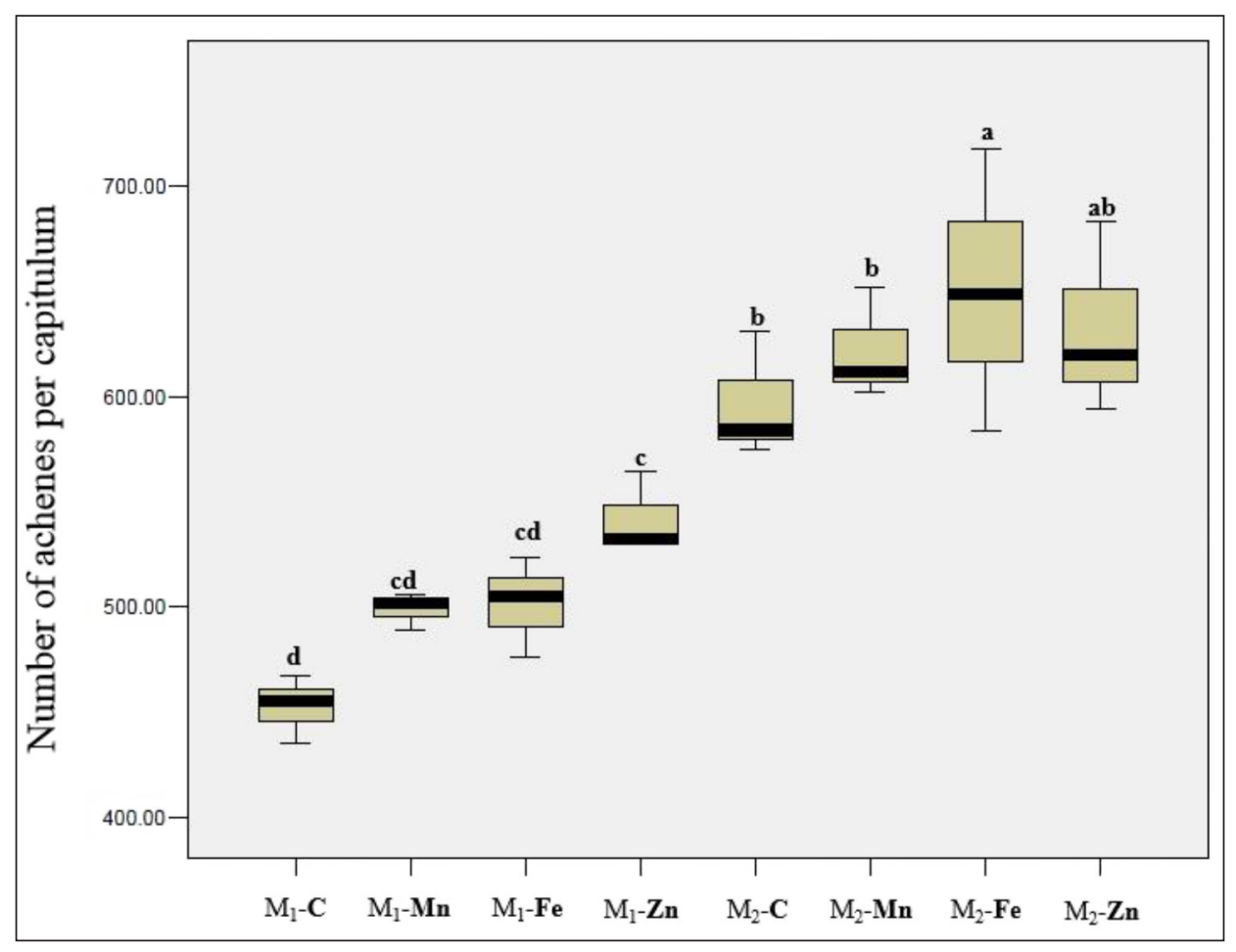

Fig. 5. The number of achenes in the main capitulum of sunflower plants affected by nanofertilizers and farmyard manure. $M_{1}$ and $M_{2}$ : without and with $20 \mathrm{tha}^{-1}$ farmyard manure application, respectively. C: control (no-micronutrient application). Values with the same letter were not significantly different 


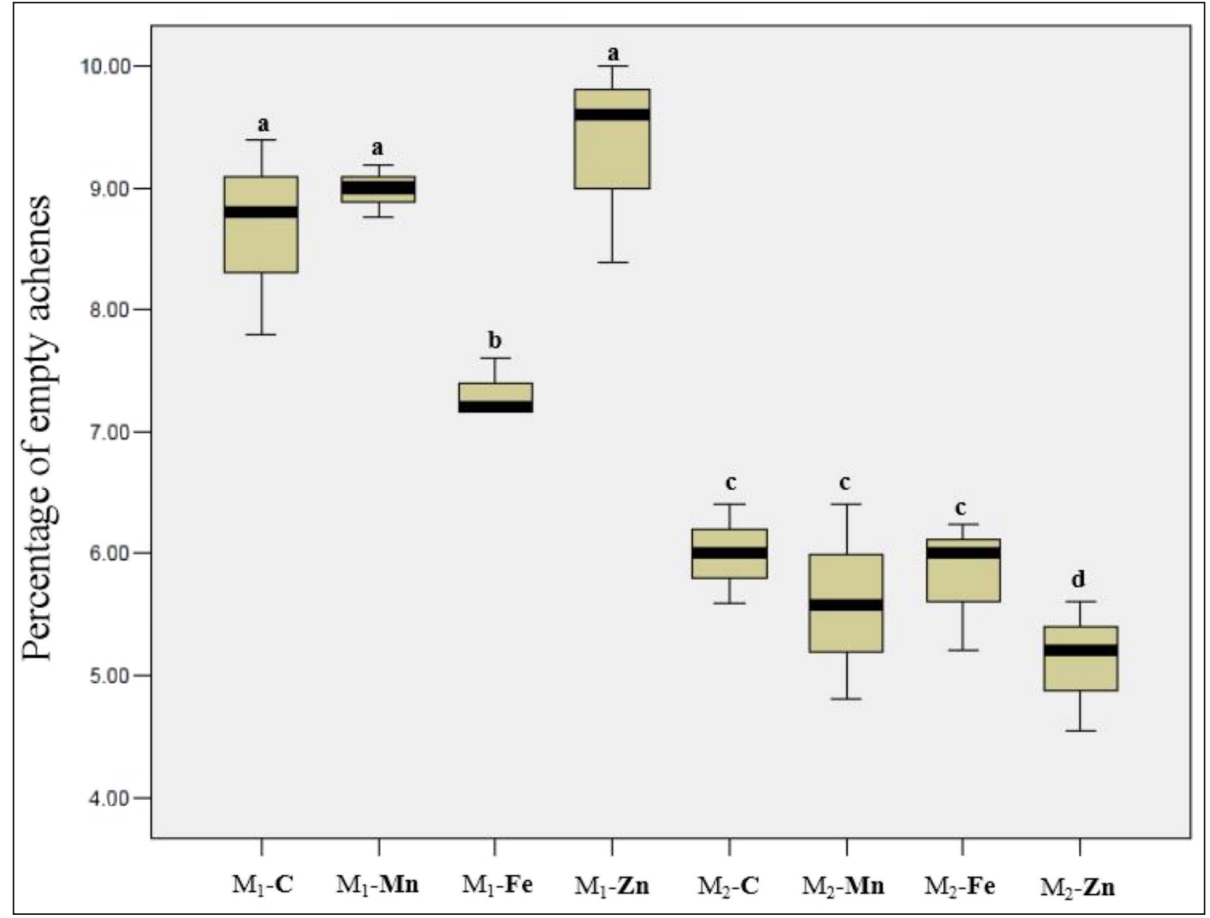

Fig. 6. The effect of farmyard manure and nano-chelated micronutrients on the percentage of empty achenes in sunflower plants in semi-arid region of Marageh. $M_{1}$ and $\mathrm{M}_{2}$ : without and with $20 \mathrm{tha}^{-1}$ farmyard manure application, respectively. C: control (no-micronutrient application)

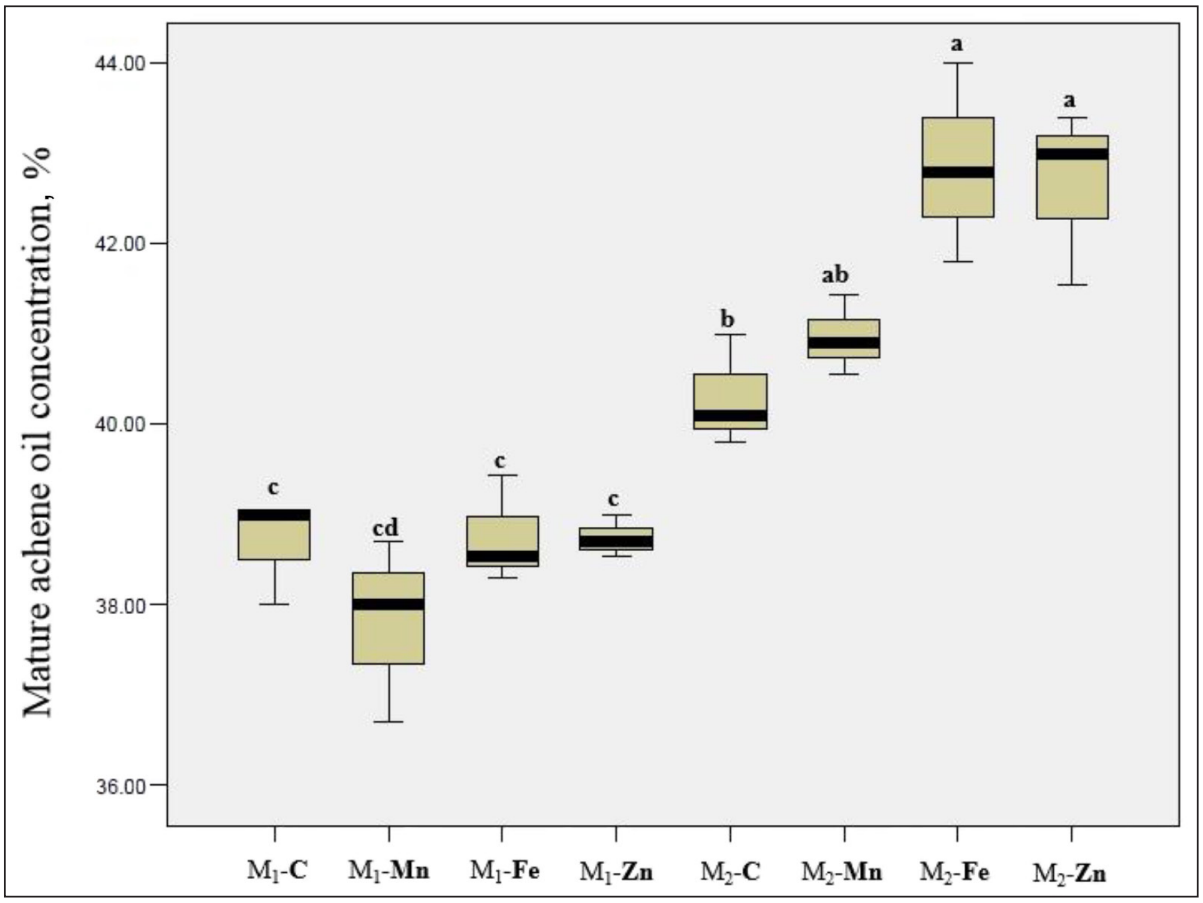

Fig. 7. The effect of farmyard manure and nano-chelated micronutrients on the oil content in the sunflower achene. $\mathrm{M}_{1}$ and $\mathrm{M}_{2}$ : without and with $20 \mathrm{tha}^{-1}$ farmyard manure application, respectively. C: control (no-micronutrient application) 
Table 2. The yield and yield component of the sunflower under different levels of farmyard manure and nano-chelated micro-nutrients

\begin{tabular}{|c|c|c|c|c|c|c|c|c|c|}
\hline $\begin{array}{c}\text { Farmyard } \\
\text { manure }\end{array}$ & NAC & EA & HAW & $\mathrm{AL}$ & AW & $\mathrm{OC}$ & AY & BY & $\mathrm{HI}$ \\
\hline & $* *$ & $* *$ & $* *$ & $* *$ & $* *$ & $* *$ & $* *$ & $* *$ & $* *$ \\
\hline non & $498.67^{b}$ & $8.57^{\mathrm{a}}$ & $4.71^{\mathrm{b}}$ & $11.24^{\mathrm{b}}$ & $4.46^{\mathrm{b}}$ & $38.49^{b}$ & $2267.17^{b}$ & $7667.91^{b}$ & $29.54^{\mathrm{b}}$ \\
\hline \multirow[t]{3}{*}{ with } & $625.3^{\mathrm{a}}$ & $5.62^{\mathrm{b}}$ & $5.62^{\mathrm{b}}$ & $12.73^{\mathrm{a}}$ & $4.95^{\mathrm{a}}$ & $41.69^{\mathrm{a}}$ & $2990.50^{a}$ & $9470.73^{\mathrm{a}}$ & $31.55^{\mathrm{a}}$ \\
\hline & \multicolumn{9}{|c|}{ Nano micro-nutrient } \\
\hline & * & NS & NS & * & NS & * & $* *$ & * & ** \\
\hline control & $524.50^{\mathrm{b}}$ & $7.33^{\mathrm{a}}$ & $4.90^{\mathrm{a}}$ & $11.24^{\mathrm{b}}$ & $4.56^{\mathrm{a}}$ & $39.48^{\mathrm{b}}$ & $2373.31^{\mathrm{c}}$ & $7886.25^{c}$ & $29.94^{\mathrm{b}}$ \\
\hline Mn & $560.50^{\mathrm{ab}}$ & $7.28^{\mathrm{a}}$ & $4.85^{\mathrm{a}}$ & $12.00^{\mathrm{ab}}$ & $4.76^{\mathrm{a}}$ & $39.38^{\mathrm{b}}$ & $2540.82^{b c}$ & $8446.26^{b c}$ & $30.03^{b}$ \\
\hline $\mathrm{Fe}$ & $575.83^{\mathrm{a}}$ & $6.57^{\mathrm{a}}$ & $4.92^{\mathrm{a}}$ & $12.67^{\mathrm{a}}$ & $4.79^{\mathrm{a}}$ & $40.81^{\mathrm{a}}$ & $2696.80^{\mathrm{ab}}$ & $8658.72^{\mathrm{ab}}$ & $30.95^{\mathrm{a}}$ \\
\hline $\mathrm{Zn}$ & $587.17^{\mathrm{a}}$ & $7.22^{\mathrm{a}}$ & $5.08^{\mathrm{a}}$ & $12.03^{\mathrm{a}}$ & $4.82^{\mathrm{a}}$ & $40.69^{a}$ & $2904.31^{\mathrm{a}}$ & $9286.30^{\mathrm{a}}$ & $31.26^{\mathrm{a}}$ \\
\hline $\mathrm{M} \times \mathrm{N}$ & NS & ** & NS & NS & NS & * & NS & NS & NS \\
\hline \multicolumn{10}{|c|}{$\begin{array}{l}\mathrm{NAC}=\text { number of achenes per capitulum, EA }=\text { Empty achenes }(\%), \mathrm{HAW}=100 \text {-achene weight }(\mathrm{g}), \mathrm{AL}=\text { achene length } \\
\mathrm{mm}), \mathrm{AW}=\text { achene width }(\mathrm{mm}), \mathrm{OC}=\text { oil concentration }(\%), \mathrm{AY}=\text { achene yield }\left(\mathrm{kg} \mathrm{ha}^{-1}\right), \mathrm{BY}=\text { biological yield }\left(\mathrm{kg} \mathrm{ha}^{-1}\right) \\
\mathrm{HI}=\text { harvest index }(\%) . \mathrm{M}=\text { farmyard manure, } \mathrm{N}=\text { micro-nutrient. } \mathrm{NS}=\text { not significant, }{ }^{*}=\text { significant at } 5 \% \text { level o } \\
\text { brobability, }{ }^{* *}=\text { significant at } 1 \% \text { level of probability. Mean values of the same category followed by different letters are } \\
\text { ignificant at } p \leq 0.05 \text { level. }\end{array}$} \\
\hline
\end{tabular}

Furthermore, application of the nanofertilizers improved the economic yield, and the highest achene yield was achieved by nano-chelated $\mathrm{Zn}$ (Table 2). A similar trend was also detected for the biological yield. In addition to the promoting impact of manure application on harvest index, application of nano-chelated $\mathrm{Zn}$ and $\mathrm{Fe}$ considerably improved this trait.

Evaluations of correlation coefficients among morphophysiological traits are shown in Fig. 8. The correlation coefficient between any two traits is approximated by the cosine of the angle between their vectors. There was a positive significant correlation between the plant height, leaf area, stem diameter, internode length, relative water content, chlorophyll concentration, main capitulum diameter, leaf number, number of achenes per capitulum, 100-achene weight, achene width, and achene yield as indicated by the small obtuse angles between their vectors $(r=\cos 0=+1)$. The highest amount of the mentioned traits were achieved by combined application of farmyard manure and nano-chelated $\mathrm{Zn}$ and $\mathrm{Fe}\left(\mathrm{M}_{2}-\mathrm{Nano} \mathrm{Fe}\right.$ and $\left.\mathrm{Zn}\right)$, as shown by the smaller angle between the two traits. These results indicate that the chlorophyll concentration, the relative water content and the main capitulum diameter can be used as acceptable criteria. Also a positive significant correlation was recorded between days to $50 \%$ flowering (DF) and the percentage of empty achenes (EA), also among the oil content and achene length. DF and EA had negative correlation with yield and yield components (Fig. 8) as indicated by the near perpendicular vectors $(r=\cos 180=-1)$.

To better understand the similarity and relationships between the treatments, the relationships are displayed in clusters (Fig. 9). Cluster analysis of treatment showed that the dendrogram was divided into three clusters. Cluster I consisted of control (no-chemical fertilizer), nano-chelated $\mathrm{Fe}$ and nano-chelated $\mathrm{Mn}$ under non-manure conditions $\left(M_{1}-C, M_{1}-M n\right.$, $\left.\mathrm{M}_{1}-\mathrm{Fe}\right)$. Cluster II contained the nano-chelated $\mathrm{Zn}$ under nan-manure condition $\left(\mathrm{M}_{1}-\mathrm{C}\right)$ and no-chemical fertilizer under manure condition $\left(\mathrm{M}_{2}-\mathrm{C}\right)$. Cluster III contained the nano-chelated $\mathrm{Zn}$, nano-chelated $\mathrm{Fe}$, and nano-chelated $\mathrm{Mn}$ under manure conditions $\left(\mathrm{M}_{2}-\mathrm{Zn}, \mathrm{M}_{2}-\mathrm{Fe}\right.$, $\mathrm{M}_{2}-\mathrm{Mn}$ ). This cluster included the most effective combined treatments that resulted in highest growth and seed yield. 


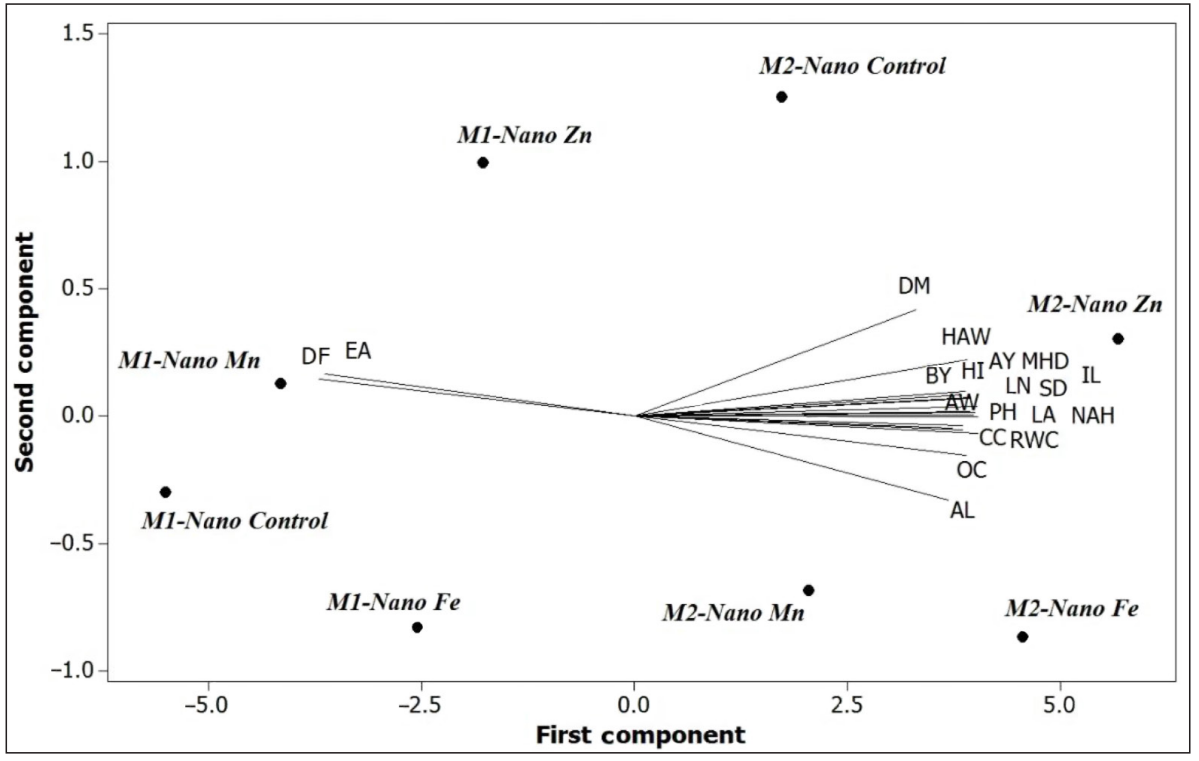

Fig. 8. Plot of the first two PCAs showing relation among various agronomical traits of sunflower plants in the semi-arid region of Marageh. $M_{1}$ and $M_{2}$ : without and with $20 \mathrm{t} \mathrm{ha}^{-1}$ farmyard manure application, respectively. C: control (no-micronutrient application). $\mathrm{PH}=$ plant height, $\mathrm{LA}=$ leaf area $\left(\mathrm{cm}^{2}\right)$ for upper green leaves, $\mathrm{SD}=$ stem diameter $(\mathrm{mm}), \mathrm{IL}=$ internode length, $\mathrm{RWC}=$ relative water content $(\%), \mathrm{CC}=$ chlorophyll concentration (SPAD unit), $\mathrm{DF}=$ days to $50 \%$ flowering, $\mathrm{MCD}=$ main capitulum diameter $(\mathrm{cm}), \mathrm{DM}=$ days to maturity, $\mathrm{LN}=$ leaf number. $\mathrm{NAC}=$ number of achenes per capitulum, EA = empty achenes (\%), HAW = 100-achene weight (g), $\mathrm{AL}=$ achene length $(\mathrm{mm}), \mathrm{AW}=$ achene width $(\mathrm{mm}), \mathrm{OC}=$ oil concentration $(\%)$, $\mathrm{AY}=$ achene yield $\left(\mathrm{kg} \mathrm{ha}^{-1}\right), \mathrm{BY}=$ biological yield $\left(\mathrm{kg} \mathrm{ha}^{-1}\right), \mathrm{HI}=$ harvest index $(\%)$

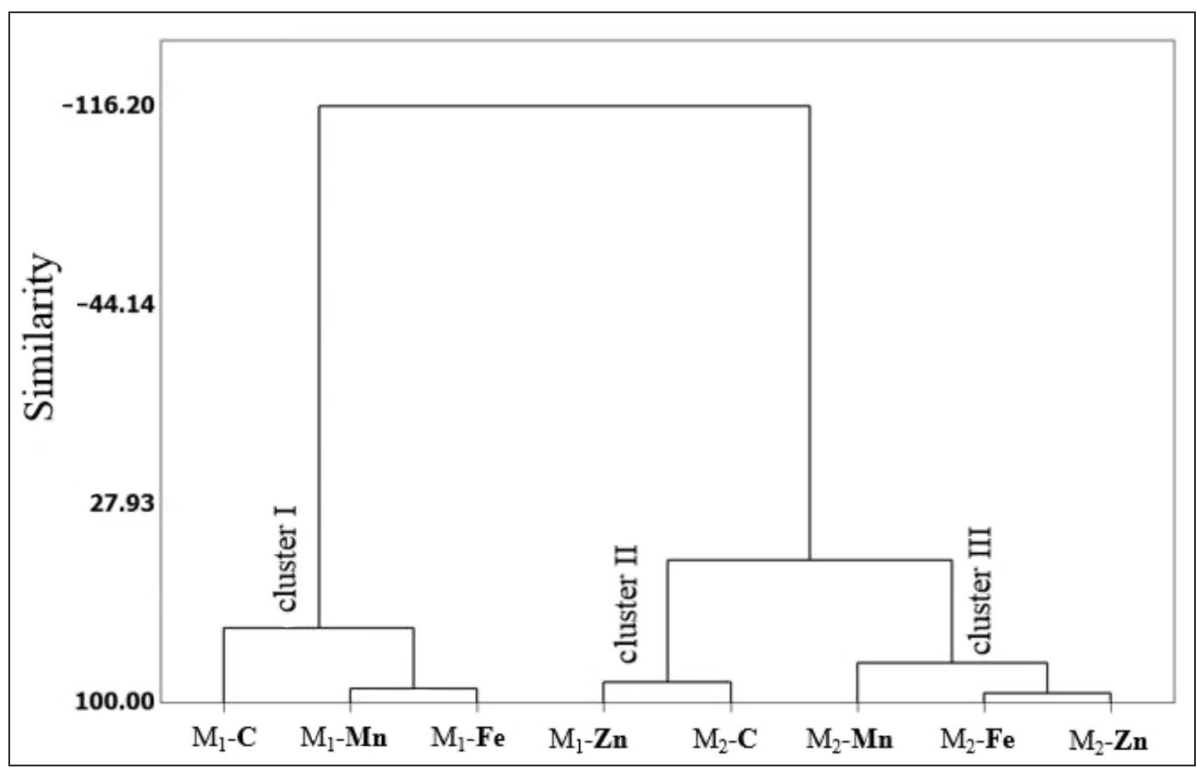

Fig. 9. Cluster analysis of combined treatments of farmyard manure and nanofertilizers in the sunflower. $\mathrm{M}_{1}$ and $\mathrm{M}_{2}$ : without and with $20 \mathrm{tha}^{-1}$ farmyard manure application, respectively. C: control (no-micronutrient application), Mn: nanochelated manganese, Fe: nano-chelated iron, Zn: nano-chelated zinc 


\section{DISCUSSION}

Results of the current study show that vegetative growth parameters considerably improved by both manure and nano-micronutrient fertilizers. The findings of the current study are consistent with those of El-Ghamry et al. (2009) who found that farmyard manure plays an important role in supplying some essential plant nutrients. The source-sink relationship determines the crop yield, and it is largely regulated by water and nutrients in semi-arid regions. The ratio between organ assimilate demand and assimilate supply at the plant scale has been found to be one of the key factors affecting plant growth and development (White et al., 2016). In the current study both sink and source organs were affected by nutrient management. Consequently, the leaf number and leaf area are noticeably affected by both organic and inorganic fertilizers. The leaf is the most important photosynthetic organ and assimilate supplying source that play critical roles in light interception, evapotranspiration and significant response to fertilizers and irrigation (Pandey, Singh, 2011). In addition to ground covering and decreasing the evaporation from soil surface, increased leaf area can directly affect the rate of photoassimilate production. In dry land cropping systems with limited water resources, reduction of the evaporation of water vapour from the soil surface can improve water conservation for critical growth stages and enhance water use efficiency (Evans, Sadler, 2007). This also accords with our earlier observations, which showed that an appropriate nutrient management considerably increased the source size in safflower (Janmohammadi et al., 2016).

Furthermore, the chlorophyll concentration noticeably responded to nutrients management and the highest value was obtained by combined application of farmyard manure and nano-chelated $\mathrm{Fe}$ and $\mathrm{Zn}$. There is a close relationship between the capacity of photosynthetic carbon dioxide fixation and the chlorophyll concentration. Therefore, the increase in the chlorophyll content can be considered equivalent to the increased source strength. A general definition of source strength should therefore con- sider the export rate of a photoassimilates from the source tissue (White et al., 2016).

Nutrient management can affect the sink size, resource allocation, and plant development. Our findings showed that sink components (the main capitulum diameter, the number of achenes per capitulum, achene weight, achene size) were dramatically improved by both organic and nanofertilizer. The formation of a large sink size might require larger vegetative organs (source size) and higher photoassimilates production. Only under a balanced source-sink ratio it is possible to achieve a higher achene yield and acceptable performance. Therefore, in the experimental trial, plants grown with the application of nanochelated $\mathrm{Zn}$ and Fe under manure conditions containing higher net assimilation rate during the growth created a greater number of achenes per plant. In this context, it can be stated that proper nutrition can increase the initiation of the reproductive organ and accelerate the cell growth, and eventually it will strengthen sinks.

Likewise, the results showed that the percentage of empty achenes significantly decreased by application of farmyard manure and nanomicronutrient fertilizers. Achene filling depends on the photoassimilates supplement from two resources: photosynthetic organs (current assimilates) and remobilization of stored resources wherein assimilates redistributed from reserve pools in vegetative tissues (Yang, Zhang, 2006). The increase of the achene weight under fertilizer application can be attributed to the improved supply of photoassimilates resulting from the abundance of essential elements that are utilized for the enlargement of the sink cells (Dordas, Sioulas, 2008), or it can be due to increased assimilates translocation from vegetative tissues to the achenes. It is encouraging to compare this finding to Janmohammadi et al. (2014), who found that manure application increased the lentil yield through the improvement of the both sink and source strength.

Phenological development affected by fertilizers application and the highest number of days to maturity recorded for plant grown by nanochelated $\mathrm{Zn}$ and $\mathrm{Fe}$ under manure condition. It 
seems that farmyard manure could bring a suitable condition for plant growth that resulted in accelerated vegetative growth, long reproductive period and greater green area duration. Farmyard manure is known to enhance soil fertility, which in turn invigorates vegetative growth and extends time to maturity. Also, the highest oil content was obtained by application of nanochelated $\mathrm{Zn}$ and Fe under manure conditions. The present findings seem to be consistent with other research which found that combination of the organic sources with inorganic nutrients gives higher oil content rapeseed and Indian mustard (Tripathi et al., 2011; De, Sinha, 2014). It has been revealed that nutrient management can affect the fatty acids biosynthesis pathway in oil crops and it seems that under nutritional imbalance a large proportion of photosynthates is diverted to protein formation. Deficiency of carbohydrates may stimulate the degradation fatty acids to acetyl co-enzyme $\mathrm{A}$ and it leads to a decreased oil content (Marschner, 2012).

The most interesting finding was that the application of nanofertilizers under non-manure conditions could not considerably affect the achene yield components and the oil content. As indicated in the chemical composition of manure, its application can supply considerable amounts of different essential macronutrients and small amounts of micronutrients to crop plants. Hence, the concomitant use of micronutrient and farmyard manure could provide balanced nutrition for crop plants and facilitate profitable and sustainable oil production. The considerable effect of $\mathrm{Zn}$ on growth parameters in this study corroborates these earlier findings (Janmohammadi, 2015). Zinc is an essential micronutrient and plays a key role as a structural constituent or regulatory cofactor of a wide range of different enzymes and proteins in many important biochemical pathways. Likewise, Zn application can show a synergistic influence on uptake of other micronutrient cations at flowering stage of the crop (Suresh et al., 2013). Despite the positive effects of nano-micronutrient fertilizers, supplementing nanofertilizers with a considerable proportion of organic manures is necessary to boost up sunflower production in semi-arid region.

\section{CONCLUSIONS}

Low soil fertility is one of the major factors limiting sunflower production and productivity in the north-west of Iran. Our findings showed that the effect of manure and nanofertilizers on most of the evaluated agro-morphological traits was significant. The data regarding vegetative growth, achene yield, and oil content clearly showed that the impact of manure addition was more prominent than nano-micronutrients fertilizer application. However, the application of farmyard manure in combination with nano-chelated micronutrients had a remarkable effect on all quantitative yield characteristics. Mean comparison between nanofertilizers revealed that the application of nano-chelated $\mathrm{Zn}$ and Fe could significantly improve some of the morphological traits and yield components. On the basis of these results it can be concluded that the application of farmyard manure along with nano-chelated $\mathrm{Zn}$ appeared to be most appropriate and suitable for harvesting a good crop of the sunflower. It seems that for the appearance of the positive effects of a nanofertilizer, soil conditions must be relatively favourable. It is further noted that in a semiarid region with relatively poor soil, nanofertilizers should not be applied alone, rather in combination with organic fertilizers to obtain the maximum yield of the crop by increasing the efficiency of the applied nanofertilizers. Our results revealed that appropriate nutrient management is an essential agronomic option for improving the achene yield of the sunflower in a highland semi-arid region under wellirrigated conditions.

\section{ACKNOWLEDGEMENTS}

We are grateful for grants (95/D/746) from the Deputy for Research and Technology, University of Maragheh. The authors wish to thank M. Amini for his valuable consultations regarding the chemical properties of nanoparticles. The authors are thankful to O. Ebrahimi, S. Afraz, and M. Medinezhad for their collaboration and technical support during the field experiment.

Received 30 August 2016 Accepted 4 November 2016 


\section{References}

1. Alloway BJ. Micronutrients and crop production: An introduction. In: Alloway BJ, editor. Micronutrient deficiencies in global crop production. Netherlands: Springer; 2008. p. 1-39.

2. Canavar Ö, Ellmer F, Chmielewski FM. Investigation of yield and yield components of sunflower (Helianthus annuus L.) cultivars in the ecological conditions of Berlin (Germany). Helia, 2010; 33(53): 117-130. 3. De B, Sinha AC. Oil and protein yield of rapeseed (Brassica campestris L.) as influenced by integrated nutrient management. SAARC Journal of Agriculture. 2014; 10(2): 41-9.

4. DeRosa MC, Monreal C, Schnitzer M, Walsh R, Sultan Y. Nanotechnology in fertilizers. Nat. Nanotechnol. 2010; 5(2): 91.

5. Dordas CA, Sioulas C. Safflower yield, chlorophyll content, photosynthesis, and water use efficiency response to nitrogen fertilization under rainfed conditions. Ind. Crops Prod. 2008; 27(1): 75-85.

6. El-Ghamry AM, El-Hamid AA, Mosa AA. Effect of farmyard manure and foliar application of micronutrients on yield characteristics of wheat grown on salt affected soil. Am Eurasian J. Agric. Environ. Sci. 2009; 5(4): 460-5.

7. Evans RG, Sadler EJ. Methods and technologies to improve efficiency of water use. Water Resour. Res. 2008; 44(7): 1-15.

8. FAOSTAT. Food and Agricultural Organisation of the United Nations. 2013; Available at: http://faostat.fao.org.

9. Gorttappeh AH, Ghalavand A, Ahmady MR, Mirnia SK. Effects of organic, inorganic and integrated fertilizers on quantitive and qualitative traits of different cultivars of sunflower (Helianthus annuus L.) in western Azarbayjan, Iran. ARJASR-Islamic Azad University. 2000; 6(2): 85-104.

10. Hayatu M, Muhammad SY, Abdu HU. Effect of water stress on the leaf relative water content and yield of some cowpea (Vigna Unguiculata L. Walp.) genotype. Int. J Sci. Tech. Res. 2014; 3(7): 148-52.
11. Janmohammadi M. Evaluation of the impact of chemical and biological fertilizer application on agronomical traits of safflower (Carthamus tinctorius L.). Proc. Latv. Acad. Sci. B Nat. Exact. Appl. Sci. 2015; 69(6): 331-5.

12. Janmohammadi $M$, Amanzadeh T, Sabaghnia N, Ion V. Effect of nano-silicon foliar application on safflower growth under organic and inorganic fertilizer regimes. Botanica Lithuanica. 2016; 22(1): 53-64.

13. Janmohammadi M, Nasiri Y, Zandi H, KorAbdali M, Sabaghnia N. Effect of manure and foliar application of growth regulators on lentil (Lens Culinaris) performance in semi-arid highland environment. Botanica Lithuanica. 2014; 20(2): 99-108.

14. Marschner P, editor. Marschner's mineral nutrition of higher plants. San Diego: Academic Press. 2012; 672 p.

15. Munir MA, Malik MA, Saleem MF. Impact of integration of crop manuring and nitrogen application on growth, yield and quality of spring planted sunflower (Helianthus annuus L.). Pak. J. Bot. 2007; 39(2): 441-9.

16. Mwahija AI. Effect of organic and inorganic nitrogen sources on growth, yield and oil content of sunflower grown in highly weathered soils of Morogoro. Doctoral dissertation, University of Nairobi. 2015; pp. 1-73.

17. Naderi MR, Danesh-Shahraki A. Nanofertilizers and their roles in sustainable agriculture. Intl. J Agri. Crop Sci. 2013; 5(19): 2229-35.

18. Nasim W, Belhouchette H, Tariq M, Fahad S, Hammad HM, Mubeen M, et al. Correlation studies on nitrogen for sunflower crop across the agroclimatic variability. Environ. Sci. Pollut. Res. 2016; 23(4): 3658-70.

19. Pandey SK, Singh H. A simple, cost-effective method for leaf area estimation. J. Bot. 2011; http://dx.doi.org/10.1155/2011/658240. p. 1-6.

20. Rai M, Ribeiro C, Mattoso L, Duran N. (Eds.). Nanotechnologies in food and agriculture. Springer. 2015; p. 347.

21. Rudrappa L, Purakayastha TJ, Singh D, Bhadraray $\mathrm{S}$. Long-term manuring and fertilization 
effects on soil organic carbon pools in a Typic Haplustept of semi-arid sub-tropical India. Soil Tillage Res. 2006; 88(1): 180-92.

22. Ryan J. Crop nutrients for sustainable agricultural production in the drought-stressed Mediterranean region. J. Agr. Sci. Tech. 2008; 10: 295-306.

23. Ryan J, Sommer R, Ibrikci H. Fertilizer best management practices: A perspective from the dryland West Asia-North Africa region. J. Agron. Crop Sci. 2012; 198(1): 57-67.

24. Schmidt MW, Torn MS, Abiven S, Dittmar T, Guggenberger G, Janssens IA, Kleber M, Kögel-Knabner I, Lehmann J, Manning DA, Nannipieri P. Persistence of soil organic matter as an ecosystem property. Nature. 2011; 478: 49-56.

25. Schneiter AA, Miller JF. Description of sunflower growth stages. Crop Sci. 1981; 21(6): 901-3.

26. Sekhon BS. Nanotechnology in agri-food production: an overview. Nanotechnol. Sci. Appl. 2014; 7: 31-53.

27. Shirani H, Hajabbasi MA, Afyuni M, Hemmat A. Effects of farmyard manure and tillage systems on soil physical properties and corn yield in central Iran. Soil Tillage Res. 2002; 68(2): 101-8.

28. Tripathi MK, Chaturvedi S, Shukla DK, Saini SK. Influence of integrated nutrient management on growth, yield and quality of Indian mustard (Brassica juncea L.) in Tarai region of northern India. J. Crop Weed. 2011; 7(2): 104-7.

29. White AC, Rogers A, Rees M, Osborne CP. How can we make plants grow faster? A source-sink perspective on growth rate. J. Exp. Bot. 2016; 67(1): 31-45.

30. Yang J, Zhang J. Grain filling of cereals under soil drying. New Phytol. (2006); 169(2): 223-36.

\section{Mohsen Janmohammadi, Akbar Seifi, Mokhtar Pasandi, Naser Sabaghnia}

\section{ORGANINIŲ TRĄŠŲ IR NANO NEORGA- NINIŲ TRĄŠŲ POVEIKIS SAULĖGRĄŽŲ AUGIMUI, DERLIUI IR ALIEJAUS KIEKIUI TINKAMOMIS LAISTYMO SĄLYGOMIS}

\section{Santrauka}

Saulègrąžos (Helianthus annuus L.) yra trečias svarbiausias maistinio aliejaus šaltinis ir sudaro apie $14 \%$ pasaulinès sẻklų aliejaus produkcijos. Nors saulègrąžos yra gerai prisitaikiusios prie pusiau sausringų regionų sąlygų, tačiau mažas dirvožemio derlingumas ir maistinių medžiagų trūkumas yra svarbus saulègrąžų produkcijos derlių ribojantis veiksnys. Šiame straipsnyje aprašomas 2015-2016 m. auginimo sezoną mokslinių tyrimų laukuose, Maragheh regione (Šiaurès Vakarų Iranas), atliktas tyrimas. Tręšimas mèšlu labai pagerino šiuos agronominius rodiklius: augalų aukštị, lapų plotị ir skaičių, tarpubamblių ilgi, stiebo ir graižo skersmenį, šakų skaičių ir ilgị, lukštavaisių ilgi, plotị ir svorị, aliejaus kiekị lukštavaisiuose. Rezultatai rodo, kad měšlu tręšiami $\left(20 \mathrm{t} / \mathrm{ha}^{-1}\right)$ augalai anksčiau pražydo ir turejo didesnę chlorofilų koncentraciją lapuose. Be to, tręšiant nano chelatiniais $\mathrm{Zn}$ ir Fe, gerokai sumažèjo tuščių lukštavaisių ir padidejjo aliejaus koncentracija, branduolių derlius ir derliaus nuemimo indeksas. Geriausias našumas buvo gautas naudojant ir nano chelatinius mikroelementus, ir méšlą.

Raktažodžiai: agronominiai rodikliai, mėšlas, nano neorganinès trąšos, mikroelementai, cinko oksidas 